\title{
CONTEMPORARY APPROACHES TO SOCIOLOGICAL REINTERPRETATION OF THE FUNCTIONS OF ARMED FORCES
}

\author{
AREVIK HAMBARDZUMYAN
}

Social institutions are structured answers to the basic needs of society. Within the framework of most strengthened interpretation, armed forces as a social institution first of all provides the need of human society to live in safe conditions. However, the mission and social functions of armed forces differ depending on the security environment, type of threats (military, non-military, and so on), type of society (military, industrial, post-industrial), different traditions of interpretation of international relations, and other significant factors.

Within the realist tradition of international relations in the frame of which the modern world is frequently described, the role of armed forces of the state is clear. "Armed forces exist to defend the state against real or potential external threats and as a coercive tool to promote and protect national interests abroad".

This approach of understanding and interpreting the mission of armed forces is presumably the most strengthened in the theoretical and ideological discourse, but still, the world is divided into regions with different conflict potential and security environments despite the contemporary trends of globalization. And if in case of one state, the realistic interpretation of armed forces is actual, there are theoretical approaches, which consider for instance in Europe the realistic approach of armed forces is a past stage, and today for armed forces other roles and new, not military threats are actual. However, the roles and mission of armed forces are really different in different regions, and for instance in Latin America, Africa, and South-Eastern Asia, armed forces traditionally were targeted to establish internal stability ${ }^{2}$.

This kind of difficulties, for theoretical generalization and modeling of armed forces, occur because the mission and structure of armed forces are defined based on various contextual factors that always undergo dynamic changes.

In this context, the first systematic attempts of sociological modeling of armed forces started after World War Two (Post World War Two or Cold War Era) ${ }^{3}$ with an aim to interpret the new situation of the world ${ }^{4}$, which in

${ }^{1}$ Edmunds T. What are armed forces for? The changing nature of military roles in Europe. International Affairs, 2006, 82(6), 1059-1075, p. 1059.

${ }^{2}$ Edmunds T. What are armed forces for? The changing nature of military roles in Europe. International Affairs, 82(6), 2006, 1059-1075, p. 1060.

${ }_{3}^{3}$ Huntington S. The Soldier and the State: The Theory and Politics of Civil-Military Relations, Harvard University Press Massachusetts, Cambridge, 1957.

${ }^{4}$ Janowitz M. The professional soldier. A Social and Political Portrait, Free Press, Glencoe, 1960. 
sociological thought is termed "modern era" or era of industrial societies.

After the Cold War (Post Cold War era), the need arose again in the sociological mind to understand and interpret what the new world would be like and which role armed forces would have in that new world.

This period both from the point of view of military sociology and international relations was the breakthrough for the reformation of the world and transformations of armed forces not only because of the End of the Cold War but also because of the ideas of neoliberalism, as well as a transition from modern to the postmodern world, the dominance of market relations, the globalization of trade, communications, finance, and other contextual factors.

As a result, the following questions of reinterpretation of Post Cold War reality became a priority in the academical agenda of Military Sociology and generally in social sciences:

- What will the new world be like (Unipolar / multipolar, peaceful / Full of wars)?

- What kind of risks and threats will be present in the "New World" (military or otherwise)?

- What will a person and society be like in the new world?

- Will the nation-state and the concept of national security continue to be key actors in international relations?

- Will the Armed Forces remain the force that can face new threats, or what will be the new roles of the Armed Forces?

Reinterpretation of Sociological thought of "Post Cold War" or "new world" reality, started to develop again in the USA and Europe (Moskos create a model of Postmodern Armed Forces ${ }^{5}$, Shaw spoke about the retreat of realist tradition and the arrival of "new", "enlight" period" and so on) and put forth an argument that "Developed western democracies" are free from the threat of armed attack.

And it seems that the new approach formed in theoretical discourse, according to which:

- The Risk of global armed conflicts is decreased ${ }^{7}$ (At least in the USA and Europe).

- "Non-military" threats and risks such as nuclear and chemical pollution, terrorism, irregular migration, large flows of refugees, etc. become priorities $^{8}$.

${ }^{5}$ Moskos Ch., Williams J., Segal D. The Postmodern Military: Armed Forces after the Cold War, 1st Edition, Oxford University press, Oxford, 2000.

${ }^{6}$ Shaw M. The Development of "Common -Risk" Society: A theoretical Overview", Military and Society in Twenty First Century Europe, A comparative Analysis, Transaction Publishers, US, 2000, p. 13-26.

${ }_{7}$ Shaw M. Post Military Society: Militarism, Demilitarization, and War at the end of Twentieth Century, Temple University Press, U.S 1991.

${ }^{8}$ Beck U. "Risk Society Towards a New Modernity" SAGE publications, US, CA 1992, first published 1986 . 
- $\quad$ Therefore, the non-military functions of the armed forces came to the fore (Military missions other than war, Peacekeeping, participation in the fight against new types of threats: terrorism, drugs, etc. $)^{9}$.

- Nation-states and national security priorities have given way to collective security systems, creating the impression that realism is gradually giving way to political idealism in the arena of international relations.

- $\quad$ Societies of the modern period, with super-militarized culture for several centuries, have given way to societies with postmodern democratic values ${ }^{10}$.

However the end of the Cold War impacted different regions of the world in different ways, for instance on the territory of the former Soviet Union, the former Yugoslavia ${ }^{11}$ and in other parts of the world, numerous interstate armed conflicts began or continued, accompanied by brutality. New independent states were formed as a result of armed confrontations. Regions with high conflict potential emerged which, being previously under the control of superpowers, later appeared in an unstable security environment, at the center of geopolitical rivalry between regional powers.

It is unclear, if these traditional, realistic notions for the armed forces of the states in such a context are a thing of the past, or are they just becoming relevant?

Thus, the aim of the article is to figure out the contexts that influenced the change of roles and mission of the armed forces, to understand not only the case of US-Europe space but also the case of "Other Camp". Are the new roles that the armed forces should have in the "New World" typical for both camps?

Let's start with the description and analysis of the contextual factors influencing the mission of the Armed Forces role change discourse:

The first factor that, according to preliminary forecasts, was to reduce the likelihood of armed conflict between states was the end of the Cold War. The collapse of the Soviet Union brought an end to decades of world order. Though the bipolar, east-west conflict was tense, it was nevertheless a clear dimension of the world order, which was well known to the political elites of the two blocs, as well as scientists and citizens ${ }^{12}$. For sure, the end of the Cold War caused the need for a theoretical reinterpretation of the world order. It should be noted that in the beginning, especially the enthusiasm and optimism of Western theorists, was very high. According to M. Shao, the end of the Cold War and the

\footnotetext{
${ }^{9}$ Moskos Ch., Williams J., Segal D. The Postmodern Military: Armed Forces after the Cold War, 1st Edition Oxford University press, Oxford, 2000.

${ }^{10}$ Shaw M. Post Military Society: Militarism, Demilitarization, and War at the end of Twentieth Century, Temple University Press, U.S 1991.

${ }_{11}$ Berdal M. Book Review: Martin Shaw, Post-Military Society: Militarism, Demilitarization and War at the End of the Twentieth Century,Cambridge: Polity Press, Millennium: Journal of International Studies, 21(3), 544-546, p. 544.

${ }^{12}$ Burk J. The Military in New Times: Adapting Armed Forces to a Turbulent World, Westview Press, London and New York, 1994, p. 3-6.
} 
impending 21 st century was to be the end of the centuries-old militarized societies typical of the culture of previous centuries. Nation-states would gradually retreat as key players in international relations due to globalization, the armed forces would be transformed into "international police forces", "managers of violence or conflict", and a "world community of general risk" would gradually be formed. And the violent conflicts that took place in different parts of the world had to "coordinate" and establish peace with the international peacekeeping forces led by "Western democracies". In the newly formed theoretical-ideological discourse, the danger of an armed attack by another state on another state was gradually decreasing. However, further theoreticalanalytical work provided a new interpretation of the collapse of the bipolar world.

"After World War II, in the Cold War era, the maintenance of order at the systemic level of international relations was based in principle on so-called bilateral strictness when the two superpowers in the system, the United States and the USSR, undertook the mission of ensuring global stability or at least controlling developments on different continents." Meanwhile, after the end of that conflict, regions with great potential for conflict, regional or superpowers with geopolitical interest in those regions, which were out of "strict" control, emerged out of control ${ }^{13}$. Many newly independent states emerged, many interstate and ethno-political conflicts began. All this made global security even more vulnerable, the environment unpredictable and uncertain. And for those newly independent states in that volatile security environment, the armed forces performed functions that were considered "traditional".

First, the protection of the state from a military threat that is considered external (in some cases internal civil wars). Significant functions from the point of view of nation-building: the transfer of national values through conscription, the guarantee of statehood by force, as well as the fulfillment of a symbolic role of sovereignty ${ }^{14}$.

Another important factor that should have reduced the likelihood of armed conflict between states is globalization ${ }^{\mathbf{1 5}}$.

Globalization in this context was interpreted in at least 3 dimensions.

First of all, it is about the tendency of economic globalization between the states, which should have reduced the armed conflicts between them due to their various economic interdependencies ${ }^{16}$. A vivid example is the replacement of the US-Japan military conflict with economic competition.

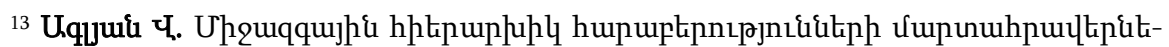
n., Unnulumip, 21-nn num, 5(63), En., 2015, เo 26:

${ }_{14}$ Edmunds T. What are armed forces for? The changing nature of military roles in Europe. International Affairs, 82(6), 1059-1075, 2006, p. 1061.

${ }_{15}$ Callaghan J., Kernic F. "New missions and tasks for the Post-Modern Military" Armed Forces and International Security: Global Trends and Issues, Lit Verlag Munster, 2003, p. 41.

${ }^{16}$ Burk. J. The Military in New Times Adapting Armed Forces to a Turbulent World, Westview Press, London and New York,1994, p. 7-8. 
In this context, the factor of neoliberalism and the dominance of market relations (since the 1980s) have been used as a factor to reduce inter-state conflicts. This theory suggests that now in the context of the market's dominance, the military doctrine should be constructed based on economic priorities: if the war is not economically 'convenient', then the States refuse to enter the war.

Meanwhile, for example, it was typical of the modern era to use all the resources of the state to ensure military security.

Y. Levy, who has studied the impact of market relations on the transformation of Israeli society and armed forces, notes that even overmilitarized Israel, which has a priority of ensuring military security, withdrew its troops from Lebanon in 1985 to integrate into international economic unions ${ }^{17}$.

The dominance of market relations reduces the likelihood of armed conflict also because societies are more demanding upon budget spending and defining the priorities and they do not support hostilities as those are not perceived as of vital importance by the society. The second aspect that is seen to be important in the context of globalization is the globalization of values. In other words, democratic values were spread in different regions of the world through the media and other means of communication. And one of the features of postmodernism was the retreat of the militarized culture of the society, the replacement of military values with democratic values. This should have led to a decline in the motivation of war within the society, and to promote peace. These two measures of globalization may have contributed to global stability in some respects, but another two measures of globalization have the opposite effect on global security.

In this context, the next measure of globalization is related to the globalization of threats and risks. Due to the high mobility, the "vulnerability" of the state borders which are typical to globalization as well as other circumstances, the new types of risks and threats acquire a universal nature, against which the states cannot fight alone ${ }^{18}$.

In this context, the non-military threats are having big importance, which the theorists also link to postmodernism. First of all, in the post-industrial period, the traditional risks to physical security have been replaced by other risks of car accidents, environmental pollution, and so on, as well as the perceptions of a people has been changed, as they no longer realize the possibility of a military threat.

It should be noted that the transformations of the "realistic" mission of the

${ }^{17}$ Levy Y. The essence of the "Market Army", Public Administration review, 70(3), 378389,2010 , p. 379.

${ }^{18}$ Shaw M. The Development of "Common -Risk" Society: A theoretical Overview" Military and Society in Twenty First Century Europe, A comparative Analysis, Transaction Publishers, US, 2000, 13-26, p. 16. 
armed forces after such examples do not seem so unambiguous even for Western Europe and the United States. The format of traditional wars is being replaced by expeditionary wars ${ }^{19}$.

The next trend, which is discussed in the context of transformations of the role of the armed forces, is the vision of the formation of a common risk society, which should later be formally formulated as a collective security body.

There will be state armed forces here, but there will be universal peacekeeping or police forces, which, if necessary, will "neutralize" the conflicts that arise in this or that part of the world. And for the beginning, at least there should be regional collective security systems, and national security should be replaced by the concept of regional security.

Linking this to the next projected trend - the suppression of national security in favor of a regional collective security strategy, it should be noted that there are rare areas that do not have conflicting security interests and have been able to establish collective security systems. For example, if we look at the South Caucasus in the context of that pushed forward vision, it is difficult to imagine that a regional security system will be formed in the near future. Gajiyev writes about that: "Currently, the region is a pile of political, economic, ideological, cultural-ethnic contradictions and conflicts, in which "difficult soluble socio-economic, national-territorial, religious, geopolitical and other interests are intertwined" ${ }^{20}$. This is an example of a regional situation, but there are many regions with such a complex security environment.

Speaking about regional collective security systems, one of the founders of the Copenhagen Security School, B. Buzan notes that as long as there is no global security body, and many regions do not have the potential to establish regional collective security systems in the near future, interstate conflicts and threats are actual, nation-state and the concept of national security will continue to be the guarantors of their security ${ }^{21}$.

Among the factors can be mentioned: feminism and pacifism, socialideological movements, both of which were against wars.

The next tendency, which theoretically influences the transformation of the role of the armed forces, has a purely human dimension and is related to postmodern perceptions. Another possible contextual factor is the complex and heterogeneous nature, change in perceptions of modern society.

All previously discussed tendencies, and this one as well, are interrelated and it is even difficult to say which one is the primary, which one is the independent variable, and which one is the dependent. The change of the

${ }^{19}$ Edmunds T. The defence dilemma in Britain, International Affairs, 86(2), 377-394, 2010 , p. 379.

20 Гаджиев К. Геополитика Кавказа. М., 2003, с. 8.

${ }^{21}$ Fjader Ch. The nation-state, national security and resilience in the age of globalization, National Emergency Supply Agency (NESA), Helsinki, Finland, Vol. 2, No. 2, 2014, 114-129, p. 118-120. 
society, in the context of security transformations, is first of all connected with the decrease of the militarized culture in the society.

If modern or industrial societies were considered super-militarized, the society of the "new world" is more in line with humanitarian, democratic values, which reduces the motivation for war. For instance, if a citizen refuses service in accordance with his conscience, it is considered normal if it is replaced by an alternative service. Also a number of characteristics of postindustrial societies, namely, the retreat of community interests in favor of the individual, the reduction of identification practices with the nation-state in the context of individual identity, and so on. Postmodernism is also characterized by changes in the perception of threats, in particular, the lack of highlighting of the military threat in the public consciousness.

Burk $^{22}$ also mentioned factors like technological growth, the increase of the citizens' education and critical thinking, the heterogeneity of the society both inside and out of the armed forces. In the modern world, individuals have stronger analytical thinking, a greater amount of the population with higher education, which provides them a more sober-examining attitude towards the world. According to Burk, modern people, compared with their grandparents are more demanding of the traditional authorities to prove the efficiency of their decisions and mostly loyal not to the nation-state but to some other group.

Civilian control of the armed forces has also increased because society's attitude not only toward armed forces but also to other institutions of government is "more skeptical" and vigilant than before. It is because of the supremacy of market values, the citizens' requirement to spend resources wisely.

The feminist approach on this issue can also be interpreted from the point of view of changes in the value system of society, which in the result should decrease the motivation of war. The feminist view considers patriarchy, masculinity and militarism as the causes of war $^{23}$. The point is that patriarchal culture causes war, because of the socialization of males as warriors. General points of agreement in feminist theoretical statements are: 1) that war and patriarchy are causally related; 2) that the ultimate roots for both reside in the sex-based division of labor; and 3 ) that both are perpetuated through the social construction of masculinities organized around the patriarchal ideals of aggression, violence, dominance, and so on.

So, the general point of this approach is that changing the patriarchal culture of society leads to decreasing war probability. Some authors argue that feministic movements for peace strengthened after Cold War, because "improving the political status of women has become a goal of international

${ }^{22}$ Burk. J. The Military in New Times Adapting Armed Forces to a Turbulent World, Westview Press, London and New York, 1994, p. 4.

${ }^{23}$ DiIorio J. Feminism and war: Theoretical issues and debates. Reference Services Review, 20(2), 1992, 51-68, p. 52. 
institutions, bilateral donors and such internationally-minded foundations as Ford and Soros. After two decades of soft-pedaling politics, focusing on women's economic development and then on human rights, the Fourth UN Conference on Women in Beijing in 1995 and the Beijing virtual conference in 2000 made women's political representation a priority, in tandem with the global turn to democracy" 24

After a detailed discussion of the factors that in one way or another influenced the security environment of the new world, and accordingly the roles of the armed forces, it is necessary to discuss the concept of smart power proposed by J. Nye. In particular, analyzing foreign policy of the USA he notes that hard power, (the military ingredient of power) remains the most important, but soft power (economical and informational impact in the result of globalization) ensures the achievement of state goals outside the field of military power. The ability to combine hard and soft power into successful strategies where they reinforce each other could be considered "smart power" (a term later used by Hillary Clinton as Secretary of State). Nye writes: "I developed the concepts further in my 2011 book on The Future of Power Including in the realm of cyber power (Nye, 2011). I made clear that soft power is not a normative concept, and it is not necessarily better to twist minds than to twist arms. "Bad" people (like Osama bin Laden) can exercise soft power. While I explored various dimensions of the concept most fully in this work, the central definition (the ability to affect others and obtain preferred outcomes by attraction and persuasion",25.

\section{Conclusions.}

After the end of the Cold War, opposing "camps" found themselves in very different security situations. For some countries of the "Western bloc", the threats of the armed attack had decreased, the armed forces did not have the adversary to resist, they were strengthening for several decades. Here, in order to increase the legitimacy of the Armed Forces in the eyes of the society, reductions in the scale of the Armed Forces and the allocated sums begin.

"New" roles of the Armed Forces, which were not connected with the realistic tradition, are beginning to be used. However, after the collapse of the Soviet Union, for newly independent states, in some cases directly involved in the war, the armed forces acted as relevant, if not priority institutions, to protect the state and society from a military threat. In addition, they acted as a symbol of statehood and sovereignty. They also performed other functions of "nationbuilding", such as the transmission of national values to generations through conscription.

${ }^{24}$ Jaquette J. Feminism and the Challenges of the "Post-Cold War" World. International Feminist Journal of Politics, 5(3), 2003, 331-354, p. 332.

25 Nye J. Soft power: the origins and political progress of a concept. Palgrave Communications, 2017, p. 2. 
The next vision of globalization was the idea that states are economically interdependent, which reduces the risk of war, and that there is a tendency for political interdependence. This should have led to the creation of global or at least regional security systems, or the formation of a common risk society. Here the armed forces of the nation-states would no longer be "key players", giving way to the international peacekeeping forces, the police forces, and so on.

However, this global security body does not exist yet, but there are regions with great potential for conflict, with many contradictions, where it is difficult to imagine the existence of regional collective security systems, at least in the near future. In this case, national security remains a priority, and the armed forces are the primary structure that ensures it.

Globalization has also affected the totality of threats and risks. In the current context of mobility, armed conflicts in one part of the world are having repercussions on other regions. Here, for example, European countries face humanitarian crises, large influxes of refugees, terrorism.

In some cases, the armies are involved in neutralizing these risks at their own borders, for example, the Greek Armed Forces support the border guard service to prevent the illegal entry of refugees.

On the other hand, for example, the USA or Great Britain carry out expedition campaigns to the conflict zones, "far from the borders of their state", in order to prevent the problem right in the epicenter. Whether this is a transformation of hostilities or support for volatile security regions is still a matter of debate.

Yet, the military (hard) power remains the most important tool for providing security and promoting foreign interests of the state, soft power ensures the achievement of state goals outside the field of military power. In the modern world, it is important to combine hard and soft power into successful strategies where they reinforce each other could be considered "smart power".

Key words: Armed forces, social functions of the army, Cold War, modernity and postmodernity, globalization

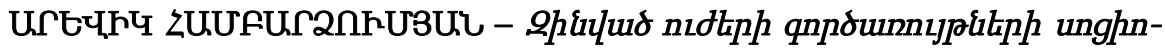

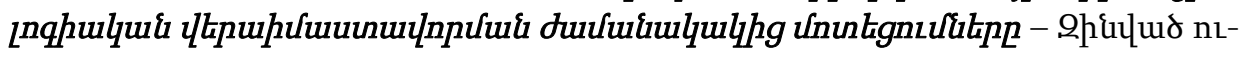

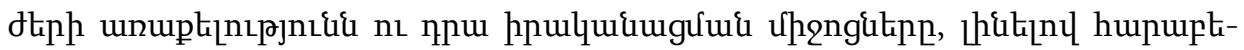

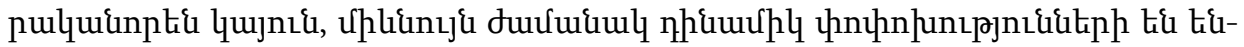

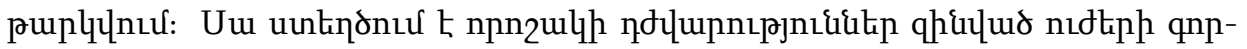

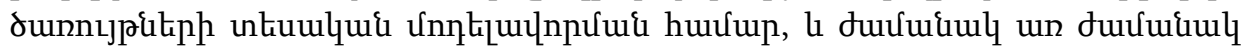

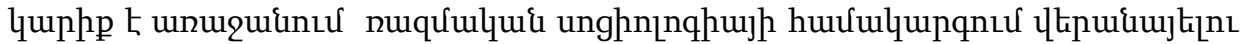

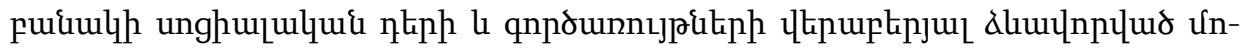

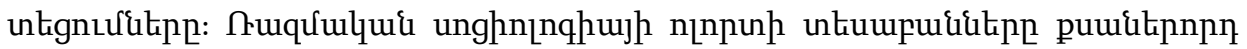

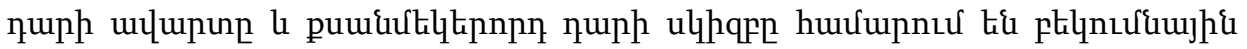




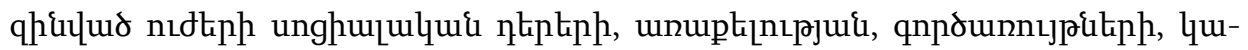

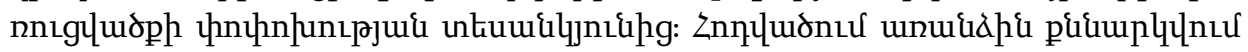

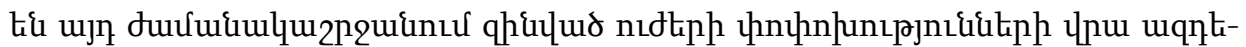

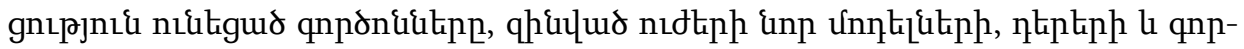

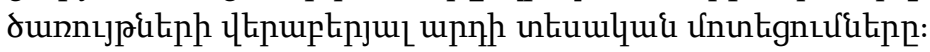

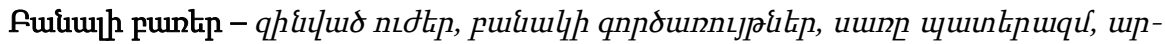

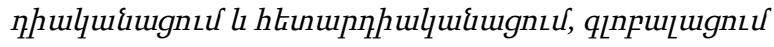

АРЕВИК АМБАРЦУМЯН - Современные подходы к социологической реинтерпретации функций вооружённых сил. - Будучи относительно стабильными, функции вооружённых сил и способы их реализации всё же периодически претерпевают определённые изменения. Это создаёт трудности для их теоретико-методологической интерпретации, а также необходимость переосмыслить имеющиеся в военной социологии концепции армии. Конец XX и начало XXI века военные социологи считают ключевым периодом в плане смены социальных ролей, миссии, функций и структуры вооружённых сил. Теоретическим подходам к их переосмыслению в современой армии уделяется в статье особое внимание.

Ключевые слова: вооруженные силь, социальные функции армии, холодная война, модернизм и постмодернизм, глобализачия

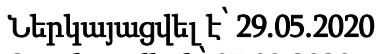

9pupunultil to 07.09.2020

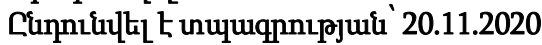




\begin{abstract}
While relatively stable, the functions of the armed forces and the ways of their implementation still undergo certain changes from time to time. This creates difficulties for their theoretical and methodological interpretation, as well as the need to rethink the concepts of the army in military sociology. The late 20 th and early 21 st centuries are considered by military sociologists to be a key period in terms of changing social roles, mission, functions and structure of the armed forces. The article pays special attention to theoretical approaches to their rethinking in the modern army.
\end{abstract}

Keywords: Armed forces, social functions of the army, Cold War, modernity and postmodernity, globalization

\title{
About Authors
}

Arevik Hambardzumyan - $\mathrm{PhD}$ student of the Chair of Applied Sociology, Yerevan State University

E mail: arevikham@gmail.com

\section{REFERENCES}

Edmunds, T. (2006). What are armed forces for? The changing nature of military roles in Europe. International Affairs, 82(6), 1059. Doi: https://doi.org/10.1111/j.1468-2346.2006.00588.x Huntington, S. (1957). The Soldier and the State: The Theory and Politics of Civil-Military Relations, Harvard University Press Massachusetts, Cambridge Janowitz, M. (1960). The professional soldier. A Social and Political Portrait, Free Press, Glencoe. Doi: https://doi.org/10.2307/1891771

Moskos, Ch., Williams, J. \& Segal D. (2000). The Postmodern Military: Armed Forces after the Cold War, 1st Edition, Oxford University press, Oxford

Shaw, M. (2000). The Development of "Common -Risk" Society: A theoretical Overview", Military and Society in Twenty First Century Europe, A comparative Analysis, Transaction Publishers, 13-26. Doi: https://doi.org/10.4324/9781315124490-3

Shaw, M. (1991). Post Military Society: Militarism, Demilitarization, and War at the end of Twentieth Century, Temple University Press

Beck, U. (1986). "Risk Society Towards a New Modernity”. SAGE publications, US, CA Berdal, M. (1992). Book Review: Martin Shaw, Post-Military Society: Militarism, Demilitarization and War at the End of the Twentieth Century, Cambridge: Polity Press, Millennium: Journal of International Studies, 21(3), 544-546. Doi: https://doi.org/10.1177/03058298920210030417 Burk, J. (1994). The Military in New Times: Adapting Armed Forces to a Turbulent World, Westview Press, London and New York, 3-6

Aglyan, V. (2015). Mijazgayin hierarkhik haraberutyunneri martahravernery, Noravanq, 21-rd dar, 5(63), Yerevan, 26

Callaghan, J. \& Kernic F. (2003). New missions and tasks for the Post-Modern Military. Armed Forces and International Security: Global Trends and Issues, Lit Verlag Munster, 41 Burk, J. (1994). The Military in New Times Adapting Armed Forces to a Turbulent World, Westview Press, London and New York, 7-8 
Levy, Y. (2010). The essence of the "Market Army", Public Administration review, 70(3), 378389. Doi: https://doi.org/10.1111/j.1540-6210.2010.02152.x

Edmunds, T. (2010). The defence dilemma in Britain, International Affairs, 86(2), 377-394. Doi: https://doi.org/10.1111/j.1468-2346.2010.00887.x

Gadjiev, K. (2003). Geopolitika Kavkaza. Moscow, 8

Fjader, Ch. (2014). The nation-state, national security and resilience in the age of globalization, National Emergency Supply Agency (NESA), Helsinki, Finland, Vol. 2, No. 2, 114-129. Doi: https://doi.org/10.1080/21693293.2014.914771

DiIorio, J. (1992). Feminism and war: Theoretical issues and debates. Reference Services Review, 20(2), 1992, 51-68. Doi: https://doi.org/10.1108/eb049153

Jaquette, J. (2003). Feminism and the Challenges of the "Post-Cold War" World. International Feminist Journal of Politics, 5(3), 331-354. Doi: https://doi.org/10.1080/1461674032000122704 Nye, J. (2017). Soft power: the origins and political progress of a concept. Palgrave Communications, 2. Doi: https://doi.org/10.1057/palcomms.2017.8 